\title{
INFLUENCE OF PASSIVE FOOT FLECTION MOVEMENTS APPLIED AFTER EXERTION ISOMETRIC WORKOUTS ON MUSCULAR BLOOD FLOW
}

\author{
Albinas Grūnovas, Jonas Poderys, \\ Eugenijus Trinkūnas, Viktoras Šilinskas \\ Lithuanian Sports University, Kaunas, Lithuania
}

\begin{abstract}
Research background and hypothesis. Blood flow intensity plays an important role in the recovery after exercising.

Research aim was to compare the effect of passive rest and passive foot movement on calf muscle blood flow applying dosed static physical loads.

Research methods. Eighteen adult males were divided into two sub-groups. Participants of the study performed two isometric 30-s workouts at 75\% of MVC with 20 minutes interval for the recovery between the workouts. During the first stage one sub-group performed workout and a passive recovery was applied while the subjects of the second sub-group performed passive foot flexion movements. During the second stage the form of recovery was changed. Arterial blood flow intensity was registered during venous occlusion plethysmography and passive foot flexion movements were performed by special mechanical equipment.

Research results. The results obtained during the study showed that maximal increase of blood flow registered at 21 second after the workout was $(52.0 \pm 2.9 \mathrm{ml} / \mathrm{min} / 100 \mathrm{ml})$, while the application of passive movements before the workout decreased the blood flow intensity $(45.0 \pm 2.6 \mathrm{ml} / \mathrm{min} / 100 \mathrm{ml})$. It was significantly $(\mathrm{p}<0.05)$ lower compared to passive rest.

Discussion and conclusions. These effects can be explained by reduced venous filling and increased venous vascular reserve capacity in the calves. The results obtained during this research allow concluding that passive foot flexion manoeuvre applied before the isometric workload faster decreases the blood flow intensity during the recovery.
\end{abstract}

Keywords: arterial blood flow recovery, isometric physical workout, passive foot movement, passive rest.

\section{INTRODUCTION}

$\mathrm{W}$ orking capacity and recovery of athlete's body after exhausting physical loads are affected by many factors, such as systemic and muscular blood flow characteristics. Various regulatory mechanisms and their interaction lead to the final result - the intensity of blood flow. With increased training workloads and contest activities, athlete recovery has probably become the main object of investigation. Fatigue levels in the process of sports training are one of the factors that determine the performance of exercise and the body adaptation to physical load. It is the recovery period, when the most significant adaptive changes occur, which are the basis for long-term adaptation.

Muscle blood flow changes directly affect the intensity of oxidative metabolic processes (Friedmann et al., 2007) suggesting that the intensification of muscle blood flow can increase the rate of tissue respiration, reduce fatigability and improve muscle working capacity. When looking for an advanced solution to this problem, researchers propose a variety of blood flow activation effects applying additional recovery measures. Extra mechanical impact on blood vessels is one of the 
self-regulatory phenomena causing vasodilator response (Boutcher, Y. N., Boutcher, S. H., 2005). The problem of the relationship between muscle blood flow and working capacity is still relevant and not fully understood (Hughson et al., 1996).

Local work carried out to failure lasts longer at a good functional state. Applying recovery exercises after the physical load, physical working capacity significantly improves for non-activated muscles during exercise compared to passive rest (Fujita et al., 2009). After physical work there are great changes in muscle blood flow. To assess the recovery measures (effect of passive rest and passive foot movement on calf muscle blood flow) we applied a functional test - static physical load of dosed duration.

Research aim was to compare the effect of passive rest and passive foot movement on calf muscle blood flow applying dosed static physical loads.

\section{RESEARCH METHODS}

Research participants were 18 persons adapted to endurance physical loads. Their age was $20.3 \pm 2.1$ years, height $178 \pm 4.2 \mathrm{~cm}$, body mass $71.2 \pm 3.5 \mathrm{~kg}$. Two studies were carried out using different recovery means (passive rest, passive foot movement). All subjects were assigned to two groups, 9 persons in each group: control and experimental, where recovery measures were administered in a certain order in each group. The control group had passive rest for 20 min between the two physical loads, and the experimental grouppassive rest for $5 \mathrm{~min}$ and passive foot movements for $15 \mathrm{~min}$. Physical working capacity is the greatest when the passive foot movements last for $15 \mathrm{~min}$. After three days the recovery measures applied to groups were interchanged - the control group received $5 \mathrm{~min}$ passive rest and $15 \mathrm{~min}$ passive foot movements, while the experimental group - $20 \mathrm{~min}$ passive rest. Such interchanging is necessary in order to avoid training and adaptation effect for subjects under the experimental conditions. In each study, after 20 min of adaptation, the calf muscle blood flow was recorded using venous occlusion plethysmograph while the subject was in a sitting position. We determined maximal voluntary contraction force of foot flexors, and two $30 \mathrm{~s}$ static physical workloads of $75 \%$ of the maximum voluntary contraction force were performed. The maximal voluntary contraction force (MVC) was determined using the dynamometric device. The maximal voluntary contraction force value was recorded three times and the highest value was taken for analysis. We captured the subjects' joints of the working knee at the $90^{\circ}$ angle and the ankle at the $70^{\circ}$ angle. Maximal muscle endurance (MME) was determined by pressing the foot on the operating plate with $75 \%$ of the maximal voluntary contraction force. The subjects had to perform a $30 \mathrm{~s}$ static physical load by pressing the plate and maintaining the same amount of force. Passive foot flexion was performed using a mechanical device. The feet were attached to the pedals which were moved by the electric motor. The angle of pedal movement and the range of motion of flexion and extension were $35^{\circ}$, and the frequency was 30 movements per minute.

Statistical analysis. The difference between the groups was considered to be reliable with Student's $t$ test statistical significance set at $p<0.05$. Before the test of means, equality of dispersion was checked up. The data are expressed as means \pm standard error. These calculations were performed using statistical functions of the SPSS Statistics 17.0.

\section{RESEARCH RESULTS}

In the control group, the arterial blood volume before the first dosed static physical load was $2.6 \pm 0.2 \mathrm{ml} / \mathrm{min} / 100 \mathrm{ml}$, and immediately after the load it increased to $46.0 \pm 2.3 \mathrm{ml} / \mathrm{min} / 100 \mathrm{ml}$, at the $21^{\text {st }} \mathrm{s}$ it was $46.2 \pm 2.3 \mathrm{ml} / \mathrm{min} / 100 \mathrm{ml}$. At the thirty-seventh and fifty-third second we observed a significant decrease in the blood flow, respectively to $25.5 \pm 2.6 \mathrm{ml} / \mathrm{min} / 100 \mathrm{ml}, 12.6 \pm 1.3 \mathrm{ml} / \mathrm{min} / 100 \mathrm{ml}$. Arterial blood flow at the one hundred sixty-ninth second was still significantly greater than the initial value (Figure 1). In the experimental group, the arterial blood volume before the first dosed static load was $2.3 \pm 0.14 \mathrm{ml} / \mathrm{min} / 100 \mathrm{ml}$, and immediately after the exercise it increased to $49.0 \pm$ $2.9 \mathrm{ml} / \mathrm{min} / 100 \mathrm{ml}$, at the $21 \mathrm{st}$ second - to $46.9 \pm$ $2.4 \mathrm{ml} / \mathrm{min} / 100 \mathrm{ml}$ (Figure 1). At the thirty-seventh and fifty-third second a considerable blood loss was observed, respectively to $23.5 \pm 2.2 \mathrm{ml} / \mathrm{min} / 100 \mathrm{ml}$, $12.9 \pm 1.3 \mathrm{ml} / \mathrm{min} / 100 \mathrm{ml}$. Arterial blood flow at the one hundred sixty-ninth second was still significantly higher than the initial value. After passive rest, the intensity of calf muscle arterial blood flow in the control group before the second physical load was significantly higher than that in the group with passive foot movements (Figure 2). 


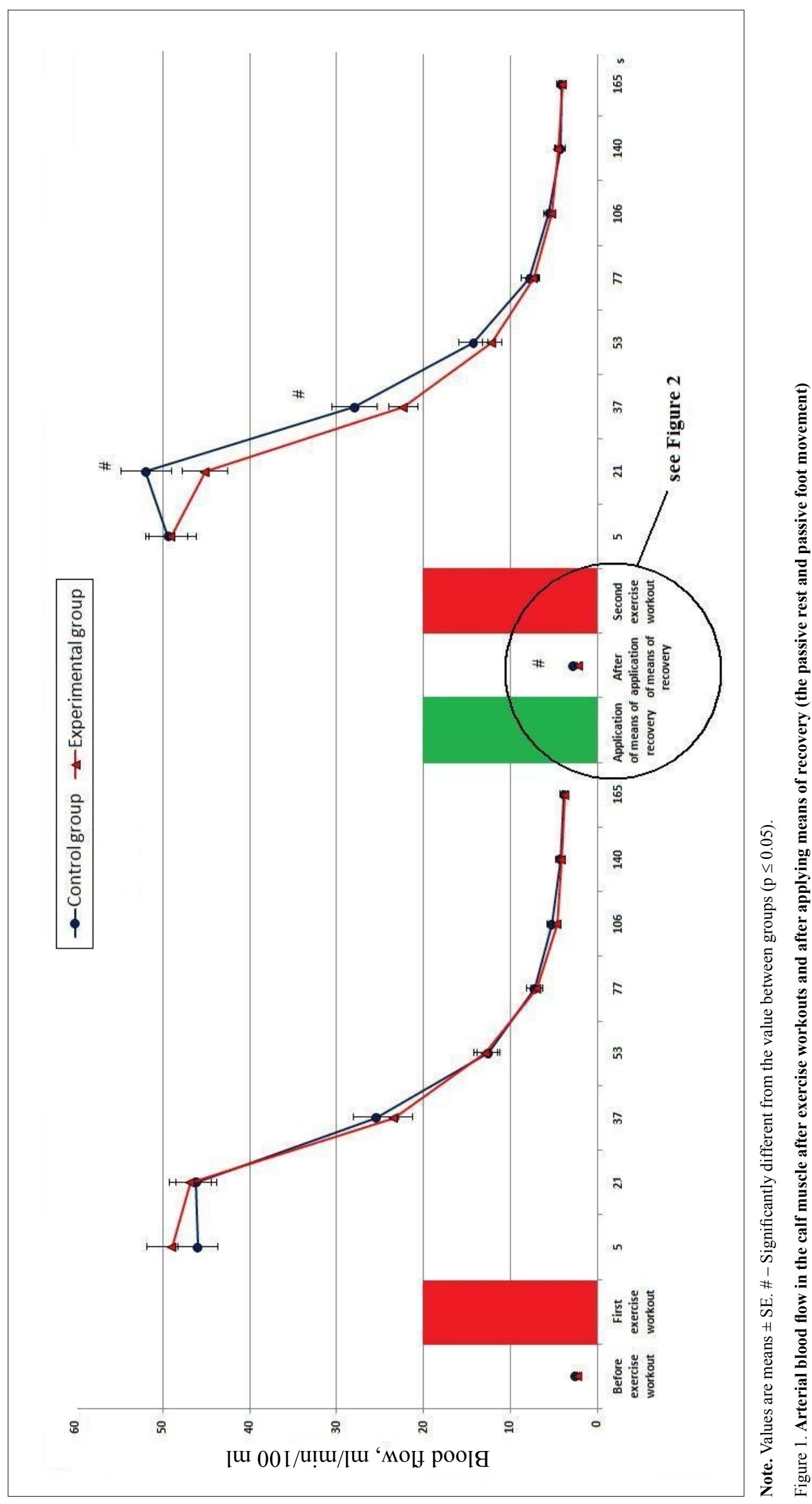




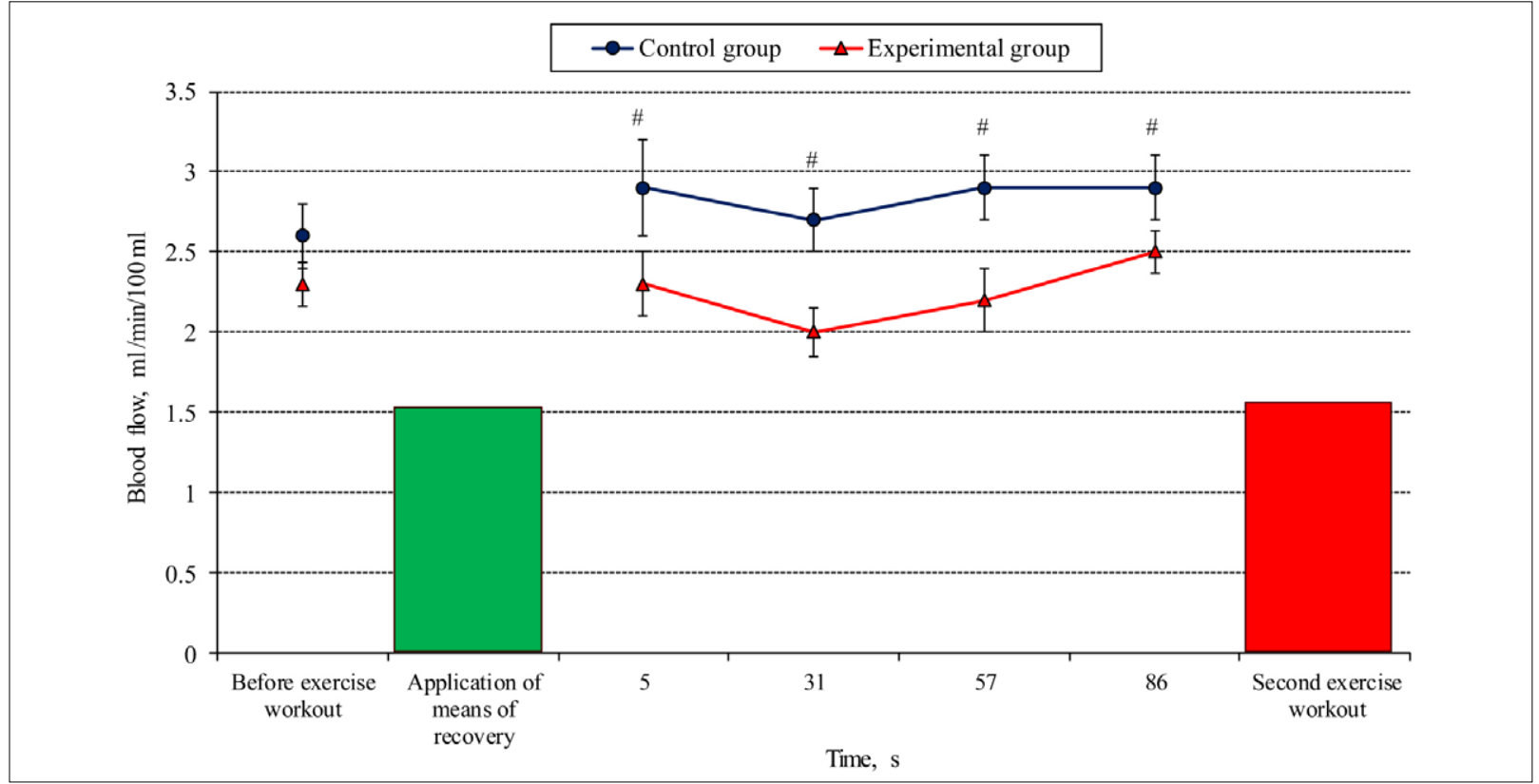

Note. Values are means \pm SE. \# - Significantly different from the value between groups $(\mathrm{p} \leq 0.05)$.

Figure 2. Arterial blood flow in the calf muscle after applying means of recovery (the passive rest and passive foot movement)

The results obtained during the study showed that maximal increase of blood flow at 21 second after the workout was registered $(52.0 \pm 2.9 \mathrm{ml} / \mathrm{min} / 100 \mathrm{ml})$, while the application of passive movement before the workout decreased the blood flow intensity $(45.0 \pm 2.6 \mathrm{ml} / \mathrm{min} / 100 \mathrm{ml})$. This was significantly $(\mathrm{p}<0.05)$ lower compared to passive rest. The same tendency of lower blood flow intensity was observed in the measurements up to 40 seconds after workouts.

After the second working hyperaemia (the twenty-first second), the largest difference in blood flow intensity was observed applying the passive rest $-5.8 \pm 1.7 \mathrm{ml} / \mathrm{min} / 100 \mathrm{ml}$, and the application of the passive foot movements resulted in $0.9 \pm$ $2.4 \mathrm{ml} / \mathrm{min} / 100 \mathrm{ml}(\mathrm{p}<0.05)$. Passive foot flexion before the second static load reduces the maximum intensity of blood flow. The lower values of the highest blood flow can be explained by the fact that passive foot flexion decreased blood filling in venous vessels and increased calf venous vascular reserve volume. After the increase in venous reserve volume, peak blood flow after working hyperaemia decreased because the increase in maximal blood flow was limited by the increased rate of venous emptying.

\section{DISCUSSION}

R. M. Enoca and D. G. Stuart (1992) showed that the results are limited to the fatigue task performed because the relative contribution of the different mechanisms to fatigue is highly task dependent. The fatigue task (to sustain $75 \%$ of MVC for $30 \mathrm{~s}$ ) combined characteristics (high force level, relatively short duration) allowing a rapid muscle recovery (Petrofsky, 1981; Petrofsky, Philips 1981), During a high force level contraction, the consumption of short-term energy supplies in anaerobic muscle fibber (type II) and the hypoxia (blood flow occlusion) of aerobic muscle fibres (type I) led to a rapid decline of muscle force (fatigue) (Lariviere et al., 2003). However, this occurs without significantly increasing the negative effects of some hypothesis concerning muscular fatigue factors associated with a low force-level contraction to fatigue that take longer to restore (Fitts, Balog, 1996).

Static physical workloads of different intensity are applied in sports practice. Static endurance is an indicator of working capacity which depends on the person's maximal effort. When the subjects perform each physical load as a percentage of MVC, the experimenter ensures equal conditions for all subjects taking into account individual differences (Розенблат, 1975). V. V. Rozenblat (Розенблат, 1975) argues that static muscle endurance in physical loads at 50 or $75 \%$ of MVC is independent physiological functional test showing the functionality of the movement mechanism. In determining the static endurance, it is necessary to use static physical load of increased intensity. V. V. Rozenblat (Розенблат, 1975) recommends that it is appropriate to use physical workloads of 
$75 \%$ MVC until complete fatigue. Static endurance of $75 \% \mathrm{MVC}$ as a test determining fatigue has several advantages: 1) fatigue occurs very quickly, 2) significant changes in the intensity of blood flow occur in the working muscles. Our previous study results showed that maximal muscle endurance (MME) of right foot flexors of athletes adapted to speed-strength physical loads was $58.9 \mathrm{~s}$, and that of athletes adapted to endurance physical loads 70.6 s. Other researchers' findings showed that maximal muscle endurance (MME) of persons not engaged in sports was $54.0 \mathrm{~s}$. The chosen duration of dosed physical load was 30 seconds because it was about a half of the maximum endurance time (van Dieen et al., 1998). The intensity of the blood flow in the working muscle after static physical workloads depends on the intensity of the load performed.

After the working hyperaemia, the maximum values of arterial blood were not immediately after the physical load, but at the twenty-first second and later. The forces compressing blood vessels disappear immediately after exercise when the muscles are relaxed. It would seem that at this time the blood pressure should fully stretch the blood vessels. Why is the blood flow the largest not immediately after physical load, but after some time? What keeps fast stretching of blood vessels, if not of all of them, but at least some of them? The data of H. V. Sparks (1964) and R. T. Grant (1930) suggest what hinders this contraction of the blood vessels which are exposed to high compression during muscle contraction. H. V. Sparks showed that the part of the artery which is exposed to a fast stretch shrinks. Even more interesting and very important is the research by R. T. Grant. He observed that chronically denervated arterioles of a rabbit responded to a slight touch by localized dilatation, but their response to a strong compression resulted in a localized shrinkage. Later, intense slowly developing dilatation occurred. Why the blood flow is the largest not immediately after the physical load, but after some time, can be explained on the basis of H. V. Sparks (1964) and R. T. Grant's work which suggests that during the load arterial blood vessels are strongly compressed, so it takes time for half-empty arterial blood vessels to fill up with blood. When they fill up with blood, the maximum values of arterial blood flow are reached.

The last question for discussion is about the duration or rest intervals between testing procedures. According to the measurements theory (Crocker, Algina, 1986), the reliability of the measurement can be increased by taking the average of multiple tests. However, in the specific case of fatigue tests, the reliability is affected not only by the random error across tests but also by the systematic error associated with the lack of recovery from the preceding fatigue tests. One way to attenuate the effect of this systematic error is to increase the rest period between tests. Studies in which repeated back muscle fatiguing contractions were performed and where a complete recovery between the tests was assumed used varying rest interval ranging between 10 and 15 min (Kondraske et al.,1987; Roy et al., 1989) and 20 min (Macarez, 1976). The rest intervals appear to be in agreement obtained with handgrip fatiguing contractions (Petrofsky, 1981). Consequently the purpose of the present study was the evaluated rest interval 20 min after performing a short fatiguing contraction.

\section{CONCLUSIONS AND PERSPECTIVES}

The results obtained during this research allow concluding that passive foot flexion manoeuvre applied before the isometric workload decreases the blood flow intensity during the recovery.

\section{REFERENCES}

Boutcher, Y. N., Boutcher, S. H. (2005). Limb vasodilatory capacity and venous capacitance of trained runners and untrained males. European Journal of Applied Physiology, 95 (1), 83-87.

Crocker, L., Algina, J. (1986). Introduction to classical and modern test theory. Forth Worth, Tex: Harcourt Brace Jovanovich College.

van Dieen, J. H., Heijblom, P., Bunkens, H. (1998). Extrapolation of time series of EMG power spectrumparameters in isometric endurance tests of trunk extensor muscles. Journal of Electromyogrphy and Kinesiology, (8), 35-44.

Enoka, R. M., Stuart, D. G. (1992). Neurobiology of muscle fatigue. Journal of Applied Physiology, (72), $1631-1648$

Fits, R. H., Balog, E. M. (1996). Effect of intracellular and extracellular ion changes on E-C coupling and skeletal muscle fatigue. Acta Physiology Scandinavia, 156 (3), 169-181.

Friedmann, B., Frese, F., Menold, E., Bartsh, P. (2007). Effects of acute moderate hypoxia on anaerobic capacity 
in endurance-trained runners. European Journal of Applied Physiology, 101 (1), 67-73.

Fujita, Y., Koizumi, K., Sukeno, S., Manabe, M., Nomura, J. (2009). Active recovery effects by previously inactivate muscles on 40 -s exhaustive cycling. Journal of Sports Science, 27 (11), 1145-1151.

Grant, R. T. (1930). Observations on local arterial reactions in rabbit's ear. Heart, 15 (3), 257-271.

Hughson, R. L., Shoemaker, J. K., Tschakovsky, M. E., Kowalchuk, J. M. (1996). Dependence of muscle $\mathrm{VO}_{2}$ on blood flow dynamics at onset of forearm exercise. Journal Applied Physiology, 81 (4), 1619-1626.

Kondraske, G. V., Deivanaygam, S., Carmihael, T., Mayer, T. G., Mooney, V. (1987). Myoelectric spectral analysis and strategies for quantifying trunk muscular fatigue, Archive. Physiology of Medicine and Rehabilitation, 68 (2), 103-110.

Lariviere, C., Gravel, D., Arsenault, A. B., Gagnon, D., Loisel, P. (2003). Muscle recovery from a short fatigue test and consequence on the reliability of EMG indices of fatigue. European Journal of Applied Physiology, 89 (2), 171-176.

Macarez, J. A. (1976). La place du reflexogramme achillen dans L exame medico-sportfil. Symbioses, 8 (4), 261-274.

Petrofsky, J. S., Phillips, C. (1981). The influence of body fat on isometric exercise performance. Ergonomics, 24 (3), 215-222.

Petrofsky, J. S. (1981). Quantification through the surface EMG of muscle fatigue and recovery during successive isometric contractions. Aviation, Space and Environment Medicine, 52 (9), 545-550.

Roy, S. H., De Luca, C. J., Casavant, D. A. (1989). Lumbar muscle fatigue and chronic lower, back pain. Spine, 14 (9), 992-1001.

Sparks, H. V. (1964). Effect of quick stretch of isolated vascular smooth muscle. Circulation Research, (15), 254-260.

Розенблат, В. В. (1975). Проблема утомления. Москва.

\title{
PASYVAUS PE்DŲ LANKSTYMO POVEIKIS BLAUZDOS RAUMENŲ KRAUJOTAKAI PO IZOMETRINIŲ FIZINIŲ KRŪVIŲ
}

\author{
Albinas Grūnovas, Jonas Poderys, \\ Eugenijus Trinkūnas, Viktoras Šilinskas \\ Lietuvos sporto universitetas, Kaunas, Lietuva
}

\section{SANTRAUKA}

Tyrimo pagrindimas ir hipotezė. Kraujotakos intensyvumas po fizinių krūviu yra svarbus veiksnys atsigavimo metu. Šio tyrimo uždavinys išsiaiškinti, kaip pasyvus peddų lankstymas po izometrinių fizinių krūvių veikia raumenų kraujotaką.

Tikslas - nustatyti pasyvaus poilsio ir pasyvaus pėdų lankstymo poveikį blauzdos raumenų kraujotakai taikant dozuotus statinius krūvius.

Metodai. Buvo tiriama18 asmenu̧, adaptuotų ištvermès fiziniams krūviams. Atlikti du tyrimai taikant skirtingas atsigavimo priemones (pasyvų poilsi, pasyvų pédų lankstyma). Visi tiriamieji suskirstyti po devynis i dvi grupes (kontrolinę ir eksperimentinę), kurioms atsigavimo priemonès buvo skiriamos tam tikra tvarka. Kiekvieno tyrimo metu po 20 minučių adaptacijos blauzdos raumenų kraujotaka buvo registruojama veniniu okliuziniu pletizmografu tiriamajam sèdint. Buvo nustatoma pedos lenkiamuju raumenų maksimalioji valinga jèga ir atliekami du $75 \%$ maksimaliosios valingos jègos $30 \mathrm{~s}$ trukmès statiniai fiziniai krūviai.

Rezultatai. Kraujotaka labiausiai padidèjo po krūvio dvidešimt pirmą sekundę ir siekẻ 52,0 2 2,9 ml/min/100 ml taikant pasyvu poilsí, o pasyviai lankstant pèdas $-45,0 \pm 2,6 \mathrm{ml} / \mathrm{min} / 100 \mathrm{ml}(\mathrm{p}<0,05)$. Trisdešimt septintą ir penkiasdešimt trečią sekundę pastebètas didelis kraujotakos sumažėjimas - atitinkamai $25.5 \pm 2,6 \mathrm{ml} / \mathrm{min} / 100 \mathrm{ml}$ ir $12,6 \pm 1,3 \mathrm{ml} / \mathrm{min} / 100 \mathrm{ml}$.

Aptarimas ir išvados. Darbo metu tiriamujų arterinès kraujagyslès buvo stipriai suspaustos, todèl reikëjo laiko joms užsipildyti krauju. Kai jos prisipildo, pasiekiamos didžiausios arterinės kraujotakos reikšmės. Rezultatai parodè, kad pasyvus pèdų lankstymas, taikytas prieš izometrinį fizini krūvị, sumažina kraujotakos intensyvumą atsigavimo metu.

Raktažodžiai: arterinès kraujotakos atsigavimas, izometrinis fizinis krūvis, pasyvus pėdų lankstymas, pasyvus poilsis.

Gauta 2013 m. birželio 17 d.

Received on 17 June, 2013

Priimta 2013 m. rugsejo 9 d.

Accepted on 9 September, 2013
Corresponding author Albinas Grūnovas

Lithuanian Sports University

Sporto str. 6, LT-44221 Kaunas

Lithuania

Tel +370 37302650

E-mail albinas.grunovas@1su.lt 